\title{
ACROMEGALY IN PRIMARY EMPTY SELLA
}

\author{
FARZANA SHUMY' ${ }^{1}$, M AZIZUL KAHHAR ${ }^{2}$
}

\begin{abstract}
Acromegaly has occasionally been found in patients with an empty sella secondary to prior pituitary irradiation and/or surgery. Active acromegaly, on the other hand, has only rarely been found in patients with a primary empty sella. The two most commonly held hypotheses concern-ing the aetiology of the primary empty sella are hydrodynamic transmission of cerebrospinal fluid pressure through a congenital defect in the diaphragm sella, and infarc-tion of the pituitary contents. Pituitary masses may undergo clinically silent infarction with development of a partial or totally empty sella by cerebrospinal fluid filling the dural herniation. Here we describe a patient who has empty sella without any prior pituitary procedures.
\end{abstract}

Keywords: Acromegaly, empty sella syndrome, growth hormone.

\section{Case Report:}

A fifty five years old gentleman, presented to the Department of Internal Medicine of Sir Salimullah Medical College and Mitford Hospital, for the evaluation of headache and abdominal discomfort, both for one year. He was a known hypertensive for last 5 years and was on atenolol. On query, he described his headache previously as hemicranial and associated with nausea but no aura. It aggravated with sound and light, and was without any signs of raised intracranial pressure. Currently it had become persistent. The abdominal discomfort was of dull aching, without any radiation, aggravating or relieving factors. Further questions revealed lethargy and increased perspiration for the last one year.

On physical examination, we found a large head with broad nose, thick lips, lower incisor teeth malocclusion, sweaty and thick skin, and hepato-splenomegaly. Atrophy of thenar muscle with positive Tinel's sign was also found. Clinically acromegaly was established.

On Investigation, there was a paradoxical elevation of GH to $5.0 \mu \mathrm{g} / \mathrm{L}$ during an oral glucose load (75gm). Thyroid Function Test, FSH, LH, Serum Prolactin were in normal level. USG revealed hepatosplenomegaly with normal liver echotexture. For the evaluation of other possible causes of hepatosplenomegaly liver function test, full blood count and endoscopy of upper GIT were done and all were within normal range. Renal function tests were also normal. Chest X-ray PA view done, excluded ectopic sources of growth hormone. Pituitary MRI showed an empty sella (Figures 1a and 1b).

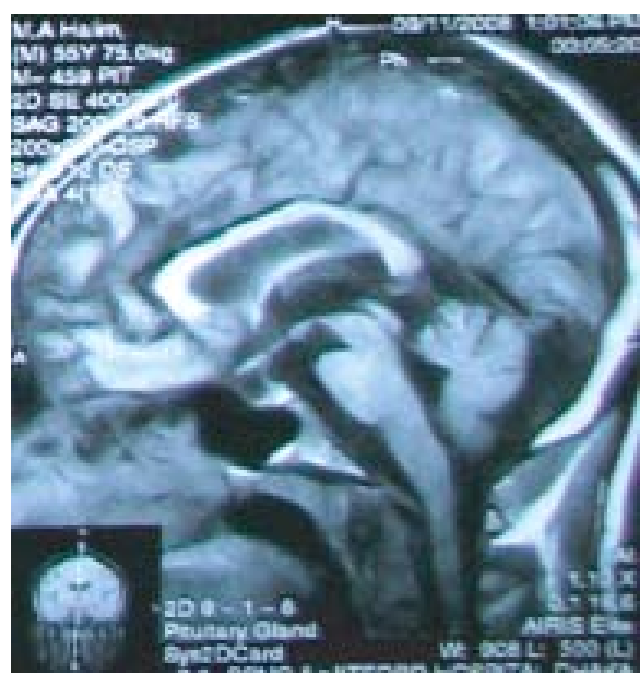

Fig.-1a: T1-weighted MRI shows empty sella

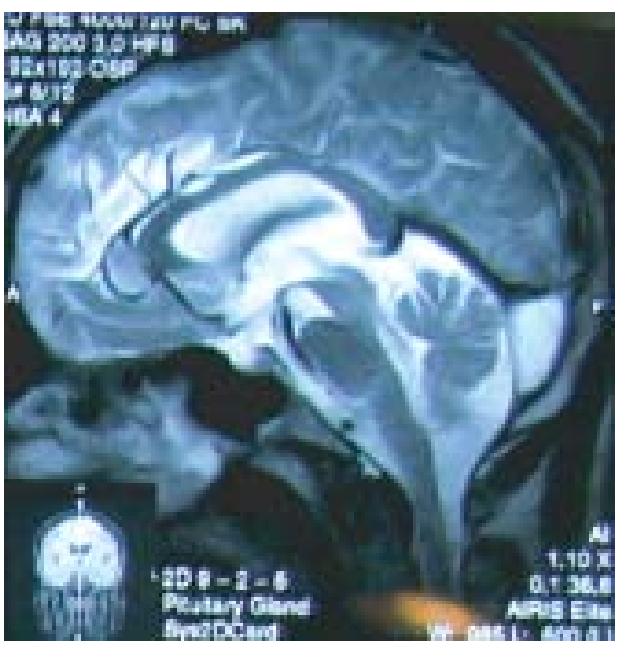

Fig.-1b: T2-weighted MRI shows empty sella

1. Postgraduate trainee, Department of Medicine, Sir Salimullah Medical College and Mitford Hospital, Dhaka.

2. Professor, Department of Medicine, Sir Salimullah Medical College and Mitford Hospital, Dhaka

Correspondence : Dr. Farzana Shumy, Postgraduate trainee, Department of Medicine, Sir Salimullah Medical College and Mitford Hospital, Dhaka. E-mail: farzanashumy@hotmail.com 
Acromegaly is a rare pituitary disorder with an estimated incidence of three to four cases per million population per year. ${ }^{1}$ Acromegaly has occasionally been found in patients with an empty sella secondary to prior pituitary irradiation and/or surgery. Active acromegaly, on the other hand, has only rarely been found in patients with a primary empty sella. ${ }^{1}$ In a retrospective study of 76 patients with empty sella, Gallardo et. al. identified only three patients with acromegaly. ${ }^{2}$ The two most commonly held hypotheses concern-ing the aetiology of the primary empty sella are: a) hydrodynamic transmission of cerebrospinal fluid pressure through a congenital defect in the diaphragm sella, and b) infarc-tion of the pituitary contents. ${ }^{1}$ Pituitary masses may undergo clinically silent infarction with development of a partial or totally empty sella by cerebrospinal fluid filling the dural herniation. ${ }^{3}$

Our patient has empty sella without any prior pituitary procedures. He might most likely have a pituitary adenoma which underwent clinically silent infarction with development of a totally empty sella. This possible in-farct did not totally ablate the hyperfunctioning tissue in this patient however, as demonstrated by elevated, nonsuppressible GH levels.

Pituitary adenomas are associated with headache. Patients of pituitary adenoma having co-existing migrane-like headache have been reported. ${ }^{4}$ A number of patients with primary empty sella presents with headache, which, most of the time is described as lateral, persistent, and datable from years. ${ }^{5}$ Our patient's presentation of headache might most likely be caused by either of the causes, probably, at first due to the adenoma, and currently associated with empty sella.

The presentation of abdominal discomfort is due to hepato-spenomegaly caused by raised level of growth hormone, as all other causes of hepato-spenomegaly were excluded by necessary biochemical, hematological, radiological and endoscopic tests.

The patient was referred to Bangladesh Institute of Research on Diabetic, Endocrine and Metabolic diseases (BIRDEM) for specialized management.

\section{References}

1. Hekimsoy Z, Yünten N \& Sivrioglu S, Coexisting acromegaly and primary empty sella syndrome. Neuroendocrinol Lett 2004; 25(4):307-309.

2. Gallardo E, Schachter D, Caceres E, Becker P, Colin E, Martinez C, Henriquez C. The empty sella: results of treatment in 76 suc-cessive cases and high frequency of endocrine and neurological disturbances. Clin Endocrinol 1992; 37:529-33.

3. Melmed S, Jameson JL. Disorders of the Anterior Pituitary and Hypothalamus. Fauci AS, Braunwald E, Kasper DL, Hauser SL, Longo DL, Jameson JL, Loscalzo J, eds. In: Harrison's Principles of Internal Medicine, $17^{\text {th }}$ Edn. The McGraw-Hill Companies, Inc, 2008; 2195-2216.

4. Lee AHS, Pituitary adenoma causing classical migraine. British Journal of Neurosurgery, 4:4,347348 .

5. De Marinis L, Bonadonna S, Bianchi A, Maira G, Giustina A, J Clin Endocrinol Metab. 90: 54715477. 